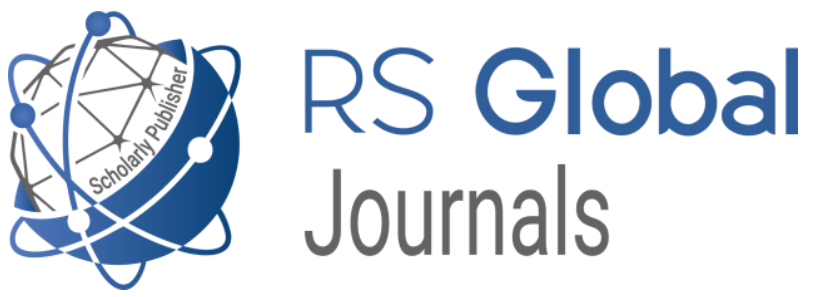

Scholarly Publisher RS Global Sp. z O.O. ISNI: 0000000484952390

Dolna 17, Warsaw, Poland 00-773

Tel: +48226022703

Email: editorial_office@rsglobal.pl

\begin{tabular}{ll} 
JOURNAL & Science Review \\
\hline p-ISSN & $2544-9346$ \\
\hline e-ISSN & $2544-9443$ \\
\hline PUBLISHER & RS Global Sp. z O.O., Poland
\end{tabular}

ARTICLE TITLE

$\operatorname{AUTHOR}(\mathbf{S})$

ARTICLE INFO

DOI

RECEIVED

ACCEPTED

PUBLISHED

LICENSE
OBTAINING OF HYDRO-INSULATION MATERIALS, PENETRANTS AND OTHER DEFICIENT LOW-TONNAGE PRODUCTS FROM PETROLEUM

Guram Khitiri, Raul Kokilashvili, Tinatin Gabunia, Madona Tsurtsumia

Guram Khitiri, Raul Kokilashvili, Tinatin Gabunia, Madona Tsurtsumia. (2020) Obtaining of Hydro-Insulation Materials, Penetrants and Other Deficient Low-Tonnage Products from Petroleum. Science Review. 6(33). doi: 10.31435/rsglobal_sr/30092020/7188 https://doi.org/10.31435/rsglobal_sr/30092020/7188 28 July 2020

08 September 2020

13 September 2020

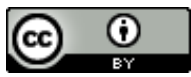

This work is licensed under a Creative Commons Attribution 4.0 International License.

(C) The author(s) 2020. This publication is an open access article. 


\title{
OBTAINING OF HYDRO-INSULATION MATERIALS, PENETRANTS AND OTHER DEFICIENT LOW- TONNAGE PRODUCTS FROM PETROLEUM
}

\author{
Guram Khitiri, PhD, TSU, Petre Meliqishvili Institute of Physical and Organic Chemistry, \\ Laboratory of Petroleum Chemistry, Tbilisi, Georgia
}

Raul Kokilashvili, PhD, TSU, Petre Meliqishvili Institute of Physical and Organic Chemistry, Laboratory of Petroleum Chemistry, Tbilisi, Georgia

Tinatin Gabunia, PhD, TSU, Petre Meliqishvili Institute of Physical and Organic Chemistry, Laboratory of Petroleum Chemistry, Tbilisi, Georgia

Madona Tsurtsumia, PhD, TSU, Petre Meliqishvili Institute of Physical and Organic Chemistry, Laboratory of Petroleum Chemistry, Tbilisi, Georgia

DOI: https://doi.org/10.31435/rsglobal_sr/30092020/7188

\section{ARTICLE INFO}

Received 28 July 2020

Accepted 08 September 2020

Published 13 September 2020

\section{KEYWORDS}

hydroinsulation materials, bitumem,

pipeline wastes, secondary tyre castings.

\begin{abstract}
Hydro-insulation of building constructions, different purpose structures is one of the most important and urgent problems of the present day. Currently concrete, ferroconcrete, metal and wooden materials are used for this purpose. Materials of this kind are not produced in the South Caucasian region. Their import, transportation, clearance by the customs and other expenses significantly increase the cost of buildings and makes it unprofitable to use them. Excreted from petroleum products - paraffins and cerezines, petrolatum, luminophores and various purpose binders, can become profitable basis for obtaining of moderm hydroinsulation materials. Their inclusion in modern hydroinsulation compositions will help to increase quality of these materials and to decrease their cost. By mixing of the goudron obtained as a result of rectification of oil pipeline sediments with milled secondary tyre casting, liquid glass, quarz sand and several additives new hydroinsulation material was obtained.
\end{abstract}

Citation: Guram Khitiri, Raul Kokilashvili, Tinatin Gabunia, Madona Tsurtsumia. (2020) Obtaining of HydroInsulation Materials, Penetrants and Other Deficient Low-Tonnage Products from Petroleum. Science Review. 6(33). doi: 10.31435/rsglobal_sr/30092020/7188

Copyright: (C) 2020 Guram Khitiri, Raul Kokilashvili, Tinatin Gabunia, Madona Tsurtsumia. This is an open-access article distributed under the terms of the Creative Commons Attribution License (CC BY). The use, distribution or reproduction in other forums is permitted, provided the original author(s) or licensor are credited and that the original publication in this journal is cited, in accordance with accepted academic practice. No use, distribution or reproduction is permitted which does not comply with these terms.

Introduction. Hydroinsulation of concrete, reinforced concrete, metal, wooden and other building structures and oil-pipelines, agglutination of metal and concrete, metal and wood etc. is one of the most important and urgent problems of the present day. Such materials are not produced in Georgia. Their import, transportation, clearance by the customs and other expenses significantly increase the cost of buildings. Thus, the use of these materials is unprofitable and senseless. The same goes for the obtaining of paraffins and cerezines, petrolatum, luminophores and various purpose binders from oils, based on which the low-tonnage, deficient, high quality and low-cost products can be produced.

The aim of our study is production of high quality hydroinsulation materials on the basis of local resources. 
Our proposal is to use oil products isolated by us from the remains of oil pipelines - ceresins, paraffins, petrolatum, wax as a basis for hydroinsulation materials.

In the experiment, we also use one of the main causes of the present-day environmental problems - the second-hand or used auto-tyre casings.

Production of the above listed products on the base of local raw materials and different types of wastes in Georgia is of utmost importance. For this purpose it is necessary to create laboratory and experimental models that will become the base for relevant manufacturing technologies.

Our strategic goal is to provide rational schemes for waste-free processing of organic and mineral wastes as well as of the deposited in pipeline mass for production of several deficient products in Georgia and avoiding environmental pollution. Our goal is to prepare different compositions of hydroinsulating materials in Georgia from the inorganic components and oil wastes. Preparation of luminophore, paraffin-cerezines and other bituminous materials, various lubricants from the wastes deposited in pipelines is stipulated as well. The latter will be included in the hydroinsulation compositions.

All this is important to avoid environmental pollution.

The calculation shows that the use of wastes is advisable and economically justified if the content of the oil components in them is more than 30\%. The residues deposited in Baku-TbilisiCeyhan oil pipeline contain more than $60-75 \%$ oil components. Separation and use of the products from these residues is prospective to obtain cheap materials.

The novelty is the use of sedimentary waste in the oil pipeline to produce low-tonnage deficient and expensive products [1, 2, 3].

Luminophore component is needed to detect invisible cracs with the methods of luminescent marking and luminescence microscopy.

Paraffines $\left(\mathrm{C}_{15}-\mathrm{C}_{35}\right)$ melt at temperature $50-65^{\circ} \mathrm{C}$ and more and cerezines $\left(\mathrm{C}_{36}-\mathrm{C}_{53}\right)$ melt at temperature within the range of $50-65^{\circ} \mathrm{C}$ and so they are of great demand for industrial and domestic purposes.

High-melting tar mass is needed to obtain insulation materials (water-proofing and anticorrosive ones).

Operating characteristics of the proposed luminophore satisfy requirements of international standards. In particular, the solutions made from it have an ability to detect invisible cracs smaller than $1 \mathrm{~mm}$. The light intensity in its greenish-yellow area is 4.5-5 times more than that of standard - uranyl nitrate. It is stable with high quantum $(40-45 \%)$ (measurement by a luxometer B-116). [4, 5]

The combination of tar, obtained from the oil pipes, and finely ground used tires produces a kind of adhesive mass, which is characterized by high hydroinsulation properties. Then various additives like quartz sand, liquid glass, polymeric materials (polyvinyl acetate, polystyrol, polyethylene glycol) are added to this mixture, which gives the adhesive mass elasticity and strength. We prepare compositions of different ratios and types to select the best option. Up to 50 compositions are obtained.

Materials and methods.

All used chemicals were of analytical grade.

Benzene Carlo Erba; Germany;

Toluene (99,5\%) Sigma-Aldrich International GmbH, Germany;

AFP Silica gel (activated fine porous silica gel) - Labstatus Ltd (Ukraine);

Petroleum ether - Sigma-Aldrich International GmbH, Germany.

Research results.

As a result of division of pipeline wax on the rectification column it was obtained the residual -5 th fraction $\left(>450{ }^{\circ} \mathrm{C}\right)$. In the experiment we used also the secondary tire casting milled with different dispersion grades.

By mixing of the $5^{\text {th }}$ fraction and milled tire castings a mixture having high hydroinsulation properties were obtained. Then the highly dispersed secondary organic components (polimeric and/or rubber) and also highly dispersed inorganic components (sand, gravel), then soluble glass (silicate solution) and other special additives were be added to this mixture. Finally, these mixtures were homogenized at the temperature $60-75{ }^{\circ} \mathrm{C}$ and intensive stirring. In this case the high elasticity and strength new hydroinsulation material with improved properties can be obtained. 
Conclusions. Obtaining of different samples of test hydroinsulation compositions is planned by changing the mass ratio of components, the types and quantities of additives. The study of mechanical, and physical and chemical parameters of each sample will allow us to select the optimal composition of the insulation material according to the specifics of its use.

It is extremely important that the production of the above materials relies on the utilization of local raw materials and various types of ecological residuals.

\section{REFERENCES}

1. Tiagunova G.V., Laroshenko Iu.G. Ecology. M. 504 p. (2005) (in Russian).

2. Паренаго О.П., Давидова С.Л. Экологические проблемы химии нефти (обзор). Нефтехимия, 1999, т. 39, № 1, c. 3-13.

3. Khitiri G. Sh., Chikvaidze I.Sh., Gabunia T.I., Tsurtsumia M. Bulletin of Geotgian National Academy of Sciences, 9, \# 3, 2015.

4. Khitiri G.Sh., Akhobadze I. Patent. Method for obtaining of Luminophor P4054, 2005 (in English).

5. Khitiri G.Sh., Chikvaidze I.Sh. Georgian patent - AP2017 13972. A method of utilization of the sludge of the pipeline. 